\title{
Economic Analysis of Taro-Sunn Hemp Intercropping With Broccoli, Green Maize and Snow Pea as Successive Crops
}

\author{
João Nacir Colombo ${ }^{1}$, Mário Puiatti², Marcelo Rodrigo Krause², Marília Cecília Bittencourt², \\ Janiele Cássia Barbosa Vieira ${ }^{3} \&$ Toshik Iarley da Silva ${ }^{2}$ \\ ${ }^{1}$ Federal Institute of Espírito Santo, Santa Teresa, Espírito Santo, Brazil \\ ${ }^{2}$ Federal University of Viçosa, Viçosa, Minas Gerais, Brazil \\ ${ }^{3}$ Federal Rural University of Pernambuco, Recife, Pernambuco, Brazil \\ Correspondence: Toshik Iarley da Silva, Department of Plant Science, Federal University of Viçosa, Viçosa, \\ Minas Gerais, Brazil. E-mail: iarley.silva@ufv.br
}

Received: March 3, 2019

Accepted: April 24, $2019 \quad$ Online Published: June 30, 2019

doi:10.5539/jas.v11n9p73

URL: https://doi.org/10.5539/jas.v11n9p73

\begin{abstract}
Although several studies about intercropping green manures with vegetable crops have already been carried out, there are few studies in which the economic analysis was performed. The aim of the present study was to evaluate the economic profitability of the taro and Crotalaria juncea consortium, as well as broccoli, green maize and snow pea grown in succession. The treatments correspond to 10 different cutting dates of the sunn hemp during its intercropping with taro (55, 70, 85, 100, 115, 130, 145, 160, 190 and 220 DAS-days after sowing), plus the monoculture of the taro. Under the legumious cover crop straw were grown in succession: broccoli, green maize and snow pea. The use of Crotalaria juncea in a consortium does not affect the productivity and economic profitability of the taro when cutting up to 130 DAS. The residual effect of Crotalaria juncea grown in consortium with taro increases the economic yield of broccoli when the cutting is performed from 145 DAS. However, it does not affect green maize and snow pea. When the taro is cultivated intercropped with Crotalaria juncea and in succession broccoli, green maize and snow pea are grown, higher yields and economic incomes are obtained by cutting the leguminous green manure up to 130 DAS.
\end{abstract}

Keywords: sustainability, total operating cost, profitability index, Crotalaria juncea, rate of return

\section{Introduction}

The production of vegetables covers about a hundred species that are grown temporarily throughout the year. In 2011, the area under cultivation of vegetables stood at 946 thousand hectares with an estimated production volume of 19.4 million tons. It is believed that the sector generates 2.4 million direct jobs ( 3.5 employee/ha), and the estimated value of the workforce is estimated at R $\$ 1.6$ billion (ABCSEM, 2011).

Nowadays, due to the population's increased awareness over healthy and pesticide-free foods, associated with the search for sustainability in agriculture systems through the rational use of natural resources and inputs for food production, the consumers are becoming more demanding in their food choices, and the producer is meeting this demand by seeking alternative farming methods. In this context, organic fertilization represents one of the alternative cultivation practices, which provides organic matter and nutrients for the plants, making it possible to reduce the amount of chemical fertilizers applied (Buzinaro et al., 2009).

The use of alternative organic inputs, such as green manure, grown in intercropping systems or sole, can contribute to the replacement of nutrients to the soil, such as nitrogen, as well as help in the cycling of nutrients, bringing to the soil surface elements that are in greater depth. The maintenance of soil organic matter and the sequestering of carbon from the atmosphere, as well as the recovery of degraded soils and weed control are also benefits from this practice (Oliveira et al., 2015).

Several studies involving the cultivation of sunn hemp as green manure alongside vegetable crops have been carried out. Puiatti et al. (2015) studied the intercropping association of the root vegetable taro (Colocasia esculenta) and sunn hemp (Crotalaria juncea) cut close to the ground and pruned at the height of the canopy. Colombo et al. (2018) evaluated the taro-sunn hemp intercropping with the leguminous plant cut in different periods. The residual effect of green manures on the successive cultivation of vegetables has also been studied. 
Vargas et al. (2011) evaluated the influence of legume biomass on the production of cabbage in two successive crops. Diniz et al. (2017), among other studies, evaluated the residual effect of Crotalaria juncea on the cultivation of zucchini and maize in sequence to broccoli.

Although several studies about intercropping green manures with vegetable crops have already been carried out, either to benefit the main crop or to provide nutrients for subsequent crops, there are few studies in which the economic analysis was performed. According to Zanatta et al. (1993), the economic analysis may or may not confirm the success of intercropping because it aims to assist farmers in decision-making, especially regarding what to plant and how to plant.

Colombo et al. (2018) performed the economic analysis of cultivating taro intercropped with Crotalaria juncea cut at different times and verified the lowest values for gross income, net income, rate of return and profitability index when the leguminous species was cut 145 days after sowing (DAS). When performing the economic analysis of vegetable crops grown in succession to cover crops, Vendruscolo et al. (2017) verified that the operating profit obtained with the production of 3.05 tons of lettuce cultivated in a field containing sorghum straw was $\mathrm{R} \$ 3,754.35$. This value surpassed in $\mathrm{R} \$ 608.06$, $\mathrm{R} \$ 1,269.60, \mathrm{R} \$ 4,052.28$ and $\mathrm{R} \$ 3,361.44$, respectively, the values obtained with the pre-harvest cultivation of millet, jack bean, pigeon pea and sunn hemp, in addition to the control treatment, in $\mathrm{R} \$ 2,426.80$. Therefore, the use of forage sorghum is recommended as a predecessor crop for crisp lettuce cultivation under no-till system. In this sense, the aim of the present study was to evaluate the economic profitability of the taro and Crotalaria juncea consortium, as well as broccoli, green maize and snow pea grown in succession.

\section{Materials and Methods}

The experiment was carried out in the field at the Plant Science Department of the Federal University of Viçosa (MG), in a 'Câmbico' Red-Yellow Argisol soil, terrace phase, in the clay-texture class ( $28 \%$ sand, $17 \%$ silt and $55 \%$ clay). The city of Viçosa stands at an altitude of $650 \mathrm{~m}, 20^{\circ} 45^{\prime} 47^{\prime \prime} \mathrm{S}$ and $42^{\circ} 49^{\prime} 13^{\prime \prime} \mathrm{W}$. According to the Köppen classification, the city presents a "Cwa" climate (humid subtropical climate), with annual averages of $1,341 \mathrm{~mm}$ of precipitation and maximum and minimum temperatures of $21.6^{\circ} \mathrm{C}$ and $14{ }^{\circ} \mathrm{C}$, respectively.

The experimental design was a randomized block design, with four replications. The experimental plots were composed of four rows spaced $1.0 \mathrm{~m}$ apart, with $3.0 \mathrm{~m}$ in length. The two central rows were considered useful, except for the plants in the end of the rows. In the consortium, the sunn hemp plants were cultivated in the same line of the taro.

The effect of the residual biomass of the taro (Colocasia esculenta) and sunn hemp (Crotalaria juncea) on the subsequent cultures of broccoli, green maize and snow pea was evaluated. The treatments correspond to 10 different cutting dates of the sunn hemp during its intercropping with taro $(55,70,85,100,115,130,145,160$, 190 and 220 DAS-days after sowing), plus the monoculture of the taro. No ploughing, soil correction or fertilization were made in the experimental plots during the three successive crops, and the cultivation of the successive crops were carried out in the same lines as the previous crops. The taro-sunn hemp cultivation was conducted from $09 / 23 / 2010$ to $06 / 04 / 2011$; broccoli from $07 / 26 / 2011$ to $10 / 1 / 2011$; the green maize from $11 / 25 / 2011$ to $02 / 25 / 2012$ and the snow pea from $05 / 23 / 2012$ to $09 / 14 / 2012$.

The taro, 'Japanese' cultivar, was harvested at 255 days after planting (DAP), when the plants were ripe, with yellowish and dry leaves. Six plants from the useful area of each plot were harvested, and the lateral rhizomes were classified according to Puiatti et al. (1990), based on its transverse diameter: 'big child' ( $>47 \mathrm{~mm}$ ), 'medium child' (40-47 mm), 'small child' (33-40 mm), and 'scrap' $(<33 \mathrm{~mm})$. The 'big child' rhizomes were ranked as 'extra fingers' and marketed in $22 \mathrm{~kg}$ capacity boxes, while 'medium' and 'small' child rhizomes were labeled as 'fingers' and marketed in $20 \mathrm{~kg}$ bags.

The single-head broccoli plants, 'BRO 68' hybrid, were harvested 65 days after transplanting (DAT), corresponding to 285 and 120 days, respectively, from the 1st and 10th cut epoch of sunn hemp. The broccoli heads within commercial standard, that is, totally closed and without signs of bolting, were packed in $13 \mathrm{~kg}$ capacity boxes.

The green maize harvest, 'AG 1051' hybrid, occurred at 90 DAP, corresponding to 432 and 269 days, respectively, from the 1st and 10th cut epoch of the sunn hemp. With the grains presenting milky state, corn cobs of ten plants of the useful area of the plot, were harvested. For the commercialization, it was considered only the corn ears with straw, which were packed in bags with a capacity of $25 \mathrm{~kg}$.

At 60 DAP started the harvest of the 'Podded Pea Flat Purple Flowered' snow pea cultivar, corresponding to 581 and 418 days, respectively, from the 1st and 10th cut season of the sunn hemp. The harvest of the unripe pods, 
presenting an approximate length of $10 \mathrm{~cm}$, was divided in seventeen (17) seasons, in the period of 50 days. After harvested, the pods were packed in boxes with a capacity of $9 \mathrm{~kg}$.

For the economic analysis, the following indicators were considered: Gross income (GI), Net income (NI), Rate of return (RR) and Profitability index (PI). The average nominal price in wholesaling in June 2011 (month of the harvest) practiced at CEASA-MG was considered to calculate the gross income (GI) of taro. It was considered the amounts paid for the $23 \mathrm{~kg}$ box of 'extra fingers' (>100 g) and the $20 \mathrm{~kg}$ bag of 'fingers' (50-100 g). For broccoli, it was considered the average wholesale price of $10 \mathrm{~kg}$ capacity boxes, in the period from 09/28/2011 to $10 / 10 / 2011$. For the green maize, it was considered the price paid per $25 \mathrm{~kg}$ bags, in the period from $02 / 23 / 2012$ to $03 / 01 / 2012$. For the snow pea, the average nominal price paid per $9 \mathrm{~kg}$ boxes in the period of $07 / 25 / 2012$ to $09 / 14 / 2012$ was considered.

The net income (NI) was obtained by the difference between gross income (GI) and total operating cost (TOC). The TOCs were calculated based on the production cost technical coefficients presented by Helmich et al. (2010) for taro, by Melo (2007) for broccoli, by Heredia Zárate et al. (2009) for green maize and EMATER-DF (2012) for snow pea. For all studied crops, modifications were made based on the necessity of operations and inputs presented in the experiment. The costs related to inputs, services, packaging and transportation were calculated from the prices practiced in the city of Viçosa-MG, from September/2010 to June/2011 for the taro, from June to October 2011 for broccoli, November/2011 to March/2012 for green maize and May to September 2012 for snow pea.

The rate of return (RR) per real (R\$) invested was obtained through the relationship between GI and TOC. The profitability index (PI) was obtained from the relationship between NI and GI and expressed as a percentage, according to Cecílio Filho et al. (2008).

The values obtained for GI, NI, RR, PI and TOC were corrected until December 31, 2018, considering the inflation rates in the period between the harvest and commercialization of the crop until 12/31/2018. Thus, 92 months were considered for taro, 87 months for broccoli, 78 months for green maize and 72 months for snow pea. The income for the period was obtained over inflation through the IGP-M Index (FGV) (Central Bank of Brazil, 2019).

The data were submitted to analysis of variance and in case of significant effect, the treatments were compared by the Scott-Knott test. All procedures were performed using a level of significance of up to $5 \%$ using the $\mathrm{R}$ software (R Core Team, 2018).

\section{Results and Discussion}

Table 1 shows the Total Operating Cost (TOC) of the taro grown as a single crop and in consortium with sunn hemp.

Table 1. Total Operating Costs (TOC) of taro (Colocasia esculentum) grown as a single crop and in consortium with sunn hemp (Crotalaria juncea)

\begin{tabular}{|c|c|c|c|c|c|c|c|c|}
\hline \multirow{2}{*}{ Description } & \multicolumn{4}{|c|}{ Taro (Single) } & \multicolumn{4}{|c|}{ Taro-Sunn Hemp Intercropping } \\
\hline & Amount & Unit & $\mathrm{UV}(\mathrm{R} \$)^{*}$ & $\mathrm{TV}(\mathrm{R} \$)^{* *}$ & Amount & Unit & $\mathrm{UV}(\mathrm{R} \$)$ & TV(R\$) \\
\hline \multicolumn{9}{|l|}{ A1) SUPPLIES } \\
\hline Seedlings & 100 & sack & 35.13 & $3,513.00$ & 100 & $\mathrm{sc}$ & 35.13 & $3,513.00$ \\
\hline Seeds/sunn hemp & - & - & - & - & 19.6 & $\mathrm{~kg}$ & 10.38 & 203.45 \\
\hline Subtotal A1 & & & & $3,513.00$ & & & & $3,716.45$ \\
\hline \multicolumn{9}{|l|}{ A2) $L A B O R$} \\
\hline Taro planting & 10 & $\mathrm{~m} / \mathrm{d}$ & 45.82 & 458.20 & 10 & $\mathrm{~m} / \mathrm{d}$ & 45.82 & 458.20 \\
\hline Sunn hemp planting & - & - & - & - & 4 & $\mathrm{~m} / \mathrm{d}$ & 45.82 & 183.28 \\
\hline Irrigation & 15 & $\mathrm{~m} / \mathrm{d}$ & 45.82 & 687.30 & 15 & $\mathrm{~m} / \mathrm{d}$ & 45.82 & 687.30 \\
\hline Weed control & 20 & $\mathrm{~m} / \mathrm{d}$ & 45.82 & 916.40 & 10 & $\mathrm{~m} / \mathrm{d}$ & 45.82 & 458.20 \\
\hline Sunn hemp cut & - & - & - & - & 2 & $\mathrm{~m} / \mathrm{d}$ & 45.82 & 91.64 \\
\hline Harvesting, cleaning, sorting and packaging & 50 & $\mathrm{~m} / \mathrm{d}$ & 45.82 & $2,291.00$ & 50 & $\mathrm{~m} / \mathrm{d}$ & 45.82 & $2,291.00$ \\
\hline Subtotal A2 & & & & $4,352.90$ & & & & $4,169.62$ \\
\hline \multicolumn{9}{|l|}{ A3) PACKAGING AND TRANSPORTATION } \\
\hline K box & 464.09 & unit & 3.05 & $1,415.47$ & 533.64 & unit & 3.05 & $1,627.60$ \\
\hline Plastic bag & 1357.5 & unit & 1.53 & $2,076.97$ & 1576 & unit & 1.53 & $2,411.28$ \\
\hline Shipping & 1851.3 & vol. & 1.53 & $2,832.49$ & 2109.6 & unit & 1.53 & $3,227.69$ \\
\hline Subtotal A3 & & & & $6,324.93$ & & & & $7,266.57$ \\
\hline
\end{tabular}




\begin{tabular}{|c|c|c|c|c|c|c|c|c|}
\hline \multicolumn{9}{|l|}{ A4) MACHINERY } \\
\hline Irrigation pump & 72 & hour & 15.27 & $1,099.44$ & 72 & hour & 15.27 & $1,099.44$ \\
\hline Tractor & 4 & hour & 91.63 & 366.52 & 4 & hour & 91.63 & 366.52 \\
\hline Subtotal A4 & & & & $1,465.96$ & & & & $1,465,96$ \\
\hline Subtotal $\mathrm{A}(\mathrm{STA})=\mathrm{A} 1+\mathrm{A} 2+\mathrm{A} 3+\mathrm{A} 4=$ & & & & $15,656.79$ & & & & 16618.60 \\
\hline \multicolumn{9}{|l|}{ B) FIXED COSTS } \\
\hline Land improvement & 260 & days & 2.29 & 595.40 & 260 & days & 2.29 & 595.40 \\
\hline Land remuneration & 1 & ha & 366.53 & 366.53 & 1 & ha & 366.53 & 366.53 \\
\hline Subtotal B & & & & 961.93 & & & & 961.93 \\
\hline \multicolumn{9}{|l|}{ C) OTHER COSTS } \\
\hline Unforeseen costs & 10 STA & $\%$ & - & 1565.68 & 10 STA & $\%$ & - & 1661.86 \\
\hline Management & $5 \mathrm{STA}$ & $\%$ & - & 782.84 & $5 \mathrm{STA}$ & $\%$ & - & 830.93 \\
\hline Subtotal C & & & & $2,348.52$ & & & & $2,492.79$ \\
\hline Total A+B $+\mathrm{C}$ & & & & 18967.24 & & & & $20,073.32$ \\
\hline Quarterly interest $(2.16 \%) \times 3$ & & & & $1,229.08$ & & & & $1,300.75$ \\
\hline Grand total & & & & $20,186.32$ & & & & $21,374.07$ \\
\hline
\end{tabular}

Note. Values corrected for inflation through the IGP-M index (FGV) in the period from May 2011 to December 2018.

* Unit value in reais; $* *$ Total value in reais; $\mathrm{m} / \mathrm{d}=$ man-day.

Data obtained from replicate 1 of taro grown as a single crop and replicate 1 of taro-sunn hemp intercropping, with cut at 55 days after sowing (DAS).

The values shown above represent one experimental unit of the taro cultivated as a monoculture and another of the taro-sunn hemp intercropping system. It should be noted that once the TOC calculation includes marketing expenses, such as packaging and shipping costs, each experimental unit presented different values according to the productivity obtained. Thus, the TOC values for the consortium system ranged from R $\$ 14,940.61$ to $\mathrm{R} \$ 22,603.16$, while in the monoculture system it ranged from $\mathrm{R} \$ 20,111.63$ to $\mathrm{R} \$ 22,637.79$. In general, for both cropping systems, the major expenses were packaging and transportation, followed by labor, machinery, land improvement and land remuneration.

When evaluating the cost of production and profitability of lettuce, radish, arugula and cabbage cultivated as a single crop and intercropped with sweet pepper, Rezende et al. (2008) observed a greater impact of inputs on TOC when compared to manpower. Although these authors did not evaluate packaging and transportation costs, this behavior differed from that observed in the present study, where the labor force had a higher impact than inputs.

When the intercropping system involves at least two vegetable crops, fertilizations are recommended for both crops (Cecílio Filho et al., 2008). In the present work, taro was cultivated in consortium with sunn hemp, a leguminous cover crop. Although sunn hemp can perform multiple functions in an agroecosystem, it is often grown for the sole purpose of improving the physical-chemical characteristics of the soil. Growing sunn hemp does not require fertilization, it does though, require manpower to sow its seed and then to cut the plants (while green or shortly after flowering) and incorporate them into the soil. This may explain the difference in the behavior of TOC items in the two consortium systems, the one that involves two species of vegetable crops and the one involving only one vegetable crop intercropped with the leguminous cover crop. Table 2 shows the TOC of broccoli, green maize and snow pea cultivation. 
Table 2. Total Operating Costs (TOC) of broccoli (Brassica oleracea var. Italica), green maize (Zea mays L.) and snow pea (Pisum sativum) grown in succession to the taro (Colocasia esculentum L. Schott) sunn hemp (Crotalaria juncea.) consortium

\begin{tabular}{|c|c|c|c|c|c|c|c|c|c|c|c|c|}
\hline \multirow{2}{*}{ Description } & \multicolumn{4}{|c|}{ Broccoli } & \multicolumn{4}{|c|}{ Green Maize } & \multicolumn{4}{|c|}{ Snow Pea } \\
\hline & Amount & Unit & $\mathrm{UV}(\mathrm{R} \$)^{*}$ & $\mathrm{TV}(\mathrm{R} \$)^{* *}$ & Amount & Unit & UV (R\$) & TV (R\$) & Amount & Unit & $\mathrm{UV}(\mathrm{R} \$)$ & TV (R\$) \\
\hline \multicolumn{13}{|l|}{ A1) SUPPLIES } \\
\hline Seeds & 30 & thousand & 45.26 & $1,357.80$ & 60 & thousand & 3.92 & 235.20 & 20 & KG & 43.63 & 872.60 \\
\hline Substrate & 20 & $\mathrm{sc}$ & 27.91 & 558.20 & - & - & - & - & - & - & - & - \\
\hline Insecticide & 1 & $\mathrm{~L}$ & 77.48 & 77.48 & - & - & - & - & - & - & - & - \\
\hline Fungicide & 5 & $\mathrm{~kg}$ & 48.28 & 241.40 & - & - & - & - & - & - & - & - \\
\hline Electricity & 1,310 & $\mathrm{kwh}$ & 0.29 & 379.90 & 516.46 & kwh & 0.28 & 144.61 & 1,102 & kwh & 0.32 & 352.64 \\
\hline Insecticide (Decis) & - & - & - & - & 1 & $\mathrm{~L}$ & 76.63 & 76.63 & - & - & & - \\
\hline Deltamethrin (ins.) & - & - & - & - & - & - & - & - & 0.5 & $\mathrm{~L}$ & 64.85 & 32.42 \\
\hline Copper oxide (fung.) & - & - & - & - & - & - & - & - & 15 & $\mathrm{~kg}$ & 36.37 & 545.55 \\
\hline Acetamiprid (ins.) & - & - & - & - & - & - & - & - & 0.2 & $\mathrm{~kg}$ & 507.49 & 101.5 \\
\hline Plain wire no. 12 (4 harvests) & - & - & - & - & - & - & - & - & 100 & $\mathrm{~kg}$ & 1.63 & $163 / 4=40.75$ \\
\hline Bob Stretcher (5 harvests) & - & - & - & - & - & - & - & - & 100 & unit & 0.70 & $70 / 5=14.00$ \\
\hline Wood (4 harvests) & - & - & - & - & - & - & - & - & 300 & unit & 3.52 & $1,056 / 4=264$ \\
\hline Sticks (4 harvests) & - & - & - & - & - & - & - & - & 20 & thousand & 105.73 & $2,114.60 / 4=528.65$ \\
\hline Raffia string yarn & - & - & - & - & - & - & - & - & 39 & $\mathrm{~kg}$ & 24.63 & 960.57 \\
\hline Subtotal A1 & & & & $2,614.38$ & & & & 456.44 & & & & $3,712.68$ \\
\hline \multicolumn{13}{|l|}{ A2) SERVICES } \\
\hline Digging & 12 & $\mathrm{~m} / \mathrm{d}$ & 60.35 & 724.20 & - & - & - & & - & - & - & - \\
\hline Seedlings formation & 2.5 & $\mathrm{~m} / \mathrm{d}$ & 60.35 & 150.87 & - & - & - & & - & - & - & - \\
\hline Transplanting & 2 & $\mathrm{~m} / \mathrm{d}$ & 60.35 & 120.70 & - & - & - & & - & - & - & - \\
\hline Application of pesticides & 6 & $\mathrm{~m} / \mathrm{d}$ & 60.35 & 362.10 & 1 & $\mathrm{~m} / \mathrm{d}$ & 59.69 & 59.69 & 12 & $\mathrm{~m} / \mathrm{d}$ & 56.39 & 676.68 \\
\hline Hand weeding & 13 & $\mathrm{~m} / \mathrm{d}$ & 60.35 & 784.55 & 12 & $\mathrm{~m} / \mathrm{d}$ & 59.69 & 716.28 & 4 & $\mathrm{~m} / \mathrm{d}$ & 56.39 & 225.56 \\
\hline Harvesting, sorting, packaging & 30 & $\mathrm{~m} / \mathrm{d}$ & 60.35 & $1,810.5$ & 18 & $\mathrm{~m} / \mathrm{d}$ & 59.69 & $1,074.42$ & 70 & $\mathrm{~m} / \mathrm{d}$ & 56.39 & 3947.30 \\
\hline Sprinkler irrigation & 5 & $\mathrm{~m} / \mathrm{d}$ & 60.35 & 301.75 & 3 & $\mathrm{~m} / \mathrm{d}$ & 59.69 & 179.07 & 6 & $\mathrm{~m} / \mathrm{d}$ & 56.39 & 338.34 \\
\hline Sowing & - & - & - & - & 3 & $\mathrm{~m} / \mathrm{d}$ & 59.69 & 179.07 & 3 & $\mathrm{~m} / \mathrm{d}$ & 56.39 & 169.17 \\
\hline Tutoring & - & - & - & - & - & - & - & - & 8 & $\mathrm{~m} / \mathrm{d}$ & 56.39 & 451.12 \\
\hline Tying & - & - & - & - & - & - & - & - & 17 & $\mathrm{~m} / \mathrm{d}$ & 56.39 & 958.63 \\
\hline Thinning & - & - & - & - & - & - & - & - & 2 & $\mathrm{~m} / \mathrm{d}$ & 56.39 & 112.78 \\
\hline Subtotal A2 & & & & $4,254.67$ & & & & $2,208.53$ & & & & $6,879.58$ \\
\hline \multicolumn{13}{|l|}{ A3) MACHINERY } \\
\hline Tractor & - & - & - & - & 4 & $\mathrm{~m} / \mathrm{d}$ & 119.38 & 477.52 & - & - & - & - \\
\hline Subtotal A3 & & & & - & & & & 477.52 & & & & - \\
\hline \multicolumn{13}{|l|}{ A4) PACKAGING AND TRANSPORTATION } \\
\hline Packages & 926 & crate & 3.02 & $2,796.52$ & 750.4 & $\mathrm{sc}$ & 0.75 & 562.80 & 646.85 & box & 1.41 & 912.06 \\
\hline Transport & 926 & crate & 1.51 & $1,398.26$ & 750.4 & $\mathrm{sc}$ & 2.24 & $1,681.00$ & 646.85 & box & 2.11 & $1,364.85$ \\
\hline Subtotal A4 & & & & $4,194.78$ & & & & $2,243.80$ & & & & $2,276.91$ \\
\hline Subtotal $\mathrm{A}(\mathrm{STA})=\mathrm{A} 1+\mathrm{A} 2+\mathrm{A} 3+\mathrm{A} 4=$ & & & & $11,063.83$ & & & & $5,386.29$ & & & & $12,869.17$ \\
\hline \multicolumn{13}{|l|}{ B) FIXED COSTS } \\
\hline Land remuneration & 1 & ha & 113.16 & 113.16 & 1 & ha & 74.60 & 74.60 & 1 & ha & 140.97 & 140.97 \\
\hline Subtotal B & & & & 113.16 & & & & 74.60 & & & & 140.97 \\
\hline \multicolumn{13}{|l|}{ C) OTHER COSTS } \\
\hline Unforeseen costs & $10 \%$ & STA & - & $1,106.38$ & $10 \%$ & STA & & 538.63 & $10 \%$ & STA & & $1,286.92$ \\
\hline Management & $5 \%$ & STA & - & 553.19 & $5 \%$ & STA & & 269.31 & $5 \%$ & STA & & 643.46 \\
\hline Subtotal C & & & & $1,659.57$ & & & & 807.94 & & & & $1,930.38$ \\
\hline Total A+ B + C & & & & $12,836.56$ & & & & $6,268.83$ & & & & $14,940.52$ \\
\hline Quarterly interest & 2.16 & $\%$ & - & 277.27 & 2.16 & $\%$ & & 135.41 & 2.16 & $\%$ & & 322.71 \\
\hline Grand total & & & & $13,113.83$ & & & & $6,404.24$ & & & & $15,263.23$ \\
\hline
\end{tabular}

Values corrected for inflation through the IGP-M index (FGV) in the period between October/2011 (broccoli), March/2012 (green maize) and September/2012 (snow pea) to December/2018.

* Unit value in reais; ** Total value in reais.

Data obtained from the 220 DAS cutting treatment of the sunn hemp, block IV (Broccoli); single taro treatment, block I (Green Maize) and the 55 DAS cutting treatment of the sunn hemp, block I (Snow Pea).

For all vegetables grown in succession to the taro-sunn hemp intercropping, the costs of services were higher than those of inputs. This behavior was not observed in the cultivation of single-head broccoli under no-tillage and conventional systems (Melo, 2007). The higher input cost observed in the broccoli cultivation may have 
occurred due to the necessity of fertilizers. In the present work, due to the incorporation of green manure into the soil, the sunn hemp, it was not necessary to use chemical or organic fertilizers, thus reducing the cost of inputs.

In the case of green maize, Heredia Zárate et al. (2009) evaluated the profitability according to the time of the hilling and verified higher costs with services when compared to inputs, even when the hilling was not realized, a result similar to the one found in the present work. In green maize cultivation, the direct sowing method may lead to a greater number of weeds when compared to broccoli cultivation, where transplanting is used. In addition, the corn ears harvesting is a very difficult activity, requiring a greater demand for labor.

No studies on the profitability evaluation of edible-podded pea (snow pea) cultivation were found. However, for the snap bean, which belongs to the same plant family and has similar morphological characteristics, EMATER data (2012) show that the costs of services were higher than those of inputs. The harvesting/sorting/packaging item was the one that most burdened the costs of services, possibly due to the difficulty in removing the pods and the excessive number of harvests. In the present study seventeen (17) harvests were registered in the period of 45 days. Table 3 shows the yield and profitability data of cultivating taro as a single crop and intercropped with Crotalaria juncea.

Table 3. Yield, Gross Income, Net Income, Rate of Return and Profitability Index of taro (Colocasia esculenta L. Schot) cultivated as a single crop and intercropped with Crotalaria juncea, with the leguminous cover crop cut at different times.

\begin{tabular}{llllll}
\hline $\begin{array}{l}\text { Cutting regime } \\
(\mathrm{DAS})\end{array}$ & $\begin{array}{l}\text { Yield } \\
\left(\mathrm{t} \mathrm{ha} \mathrm{h}^{-1}\right)\end{array}$ & $\begin{array}{l}\text { Gross Income } \\
\left(\mathrm{R} \$ \mathrm{ha}^{-1}\right)\end{array}$ & $\begin{array}{l}\text { Net Income } \\
\left(\mathrm{R} \$ \mathrm{ha}^{-1}\right)\end{array}$ & $\begin{array}{l}\text { Rate of Return } \\
\left(\mathrm{R} \$ \mathrm{R} \$^{-1}\right)\end{array}$ & $\begin{array}{l}\text { Profitability Index } \\
(\%)\end{array}$ \\
\hline Control & $47.10 \mathrm{a}$ & $76546,47 \mathrm{a}$ & $55,075.14 \mathrm{a}$ & $3.56 \mathrm{a}$ & $71.84 \mathrm{a}$ \\
55 & $40.95 \mathrm{a}$ & $62,889.23 \mathrm{a}$ & $43,064.87 \mathrm{a}$ & $3.16 \mathrm{a}$ & $67.89 \mathrm{a}$ \\
70 & $46.22 \mathrm{a}$ & $74,554.70 \mathrm{a}$ & $53,139.92 \mathrm{a}$ & $3.47 \mathrm{a}$ & $71.00 \mathrm{a}$ \\
85 & $39.02 \mathrm{a}$ & $62,826.75 \mathrm{a}$ & $42,929.09 \mathrm{a}$ & $3.15 \mathrm{a}$ & $68.14 \mathrm{a}$ \\
100 & $40.83 \mathrm{a}$ & $67,211.16 \mathrm{a}$ & $46,680.46 \mathrm{a}$ & $3.47 \mathrm{a}$ & $69.40 \mathrm{a}$ \\
115 & $40.00 \mathrm{a}$ & $58,638.72 \mathrm{a}$ & $39,230.73 \mathrm{a}$ & $3.03 \mathrm{a}$ & $66.87 \mathrm{a}$ \\
130 & $37.33 \mathrm{a}$ & $61,248.46 \mathrm{a}$ & $41,377.48 \mathrm{a}$ & $3.08 \mathrm{a}$ & $67.45 \mathrm{a}$ \\
145 & $27.91 \mathrm{~b}$ & $43,853.06 \mathrm{~b}$ & $25,423.86 \mathrm{~b}$ & $2.36 \mathrm{~b}$ & $53.55 \mathrm{~b}$ \\
160 & $29.30 \mathrm{~b}$ & $43,853.06 \mathrm{~b}$ & $26,327.05 \mathrm{~b}$ & $2.49 \mathrm{~b}$ & $59.40 \mathrm{~b}$ \\
190 & $29.32 \mathrm{~b}$ & $42,751.02 \mathrm{~b}$ & $25,253.64 \mathrm{~b}$ & $2.44 \mathrm{~b}$ & $58.80 \mathrm{~b}$ \\
220 & $28.46 \mathrm{~b}$ & $42,933.35 \mathrm{~b}$ & $25,522.73 \mathrm{~b}$ & $2.45 \mathrm{~b}$ & $58.57 \mathrm{~b}$ \\
\hdashline $\mathrm{P}$ Value & $<0.001$ & $<0.001$ & $<0.001$ & $<0.001$ & $<0.001$ \\
\hline
\end{tabular}

Note. Means within a column followed by the same letter are statistically equal to each other by the Scott-Knott test at the level of up to $5 \%$ probability.

Values corrected for inflation through the IGP-M index (FGV) in the period from May 2011 to December 2018.

In relation to the yield and all the economic indicators of the taro cultivation, both monocropping and intercropping systems presented higher values when the green manure cover crop was cut until 130 DAS, when compared to 145 DAS on. A similar result was observed by Puiatti et al. (2015) when evaluating the taro-sunn hemp intercropping, with the leguminous plant cut at 75, 105, 135, 165, 195 and 225 DAS. These authors verified a reduction in the number of commercial and 'big child' rhizomes per plant, affecting taro production, when the green manure was cut at 135 DAS on.

The reduced taro yield observed in treatments where $C$. juncea remained for a longer time in the consortium may be due to the shading degree provided by the leguminous plant. Gondim et al. (2007) verified that the increase in artificial shade intensity from 0 to $50 \%$ caused a reduction in taro productivity. They also state that shade intensities of up to $18 \%$ during the whole plant cycle or in the first three months, or from the 3rd to the 6th month after planting, little affect the development of taro plants and the production of rhizomes.

The higher productivity of commercial taro rhizomes obtained in both monocropping and intercropping systems, with the legume cut up to 130 DAS, affected all the economic indicators evaluated. Even though in the intercropping system, items such as seed material, planting and cutting of sunn hemp add up to the TOC, the shading provided by the cover crop reduced the infestation of invasive plants, thus reducing the labor with weeds (Table 1). The fact that the cultivation is carried out in the form of a consortium does not mean that there will be 
an increase in the cost of production of the cash crop. Rezende et al. (2009) verified a 34\%, 24.7\%, 21.3\% and $20.8 \%$ reduction in the TOC of cabbage, arugula, lettuce and radish, respectively, intercropped with sweet pepper in relation to their respective single crops. Table 4 shows the yield and profitability data of broccoli grown in succession to taro cultivated singly and intercropped with Crotalaria juncea.

Table 4. Yield, Gross Income, Net Income, Rate of Return and Profitability Index of broccoli (Brassica oleracea var. Italica) grown in succession to taro (Colocasia esculenta L. Schot) cultivated as a single crop and intercropped with Crotalaria juncea, with the leguminous cover crop cut at different times

\begin{tabular}{llllll}
\hline $\begin{array}{l}\text { Cutting regime } \\
(\mathrm{DAS})\end{array}$ & $\begin{array}{l}\text { Yield } \\
\left(\mathrm{t} \mathrm{ha}^{-1}\right)\end{array}$ & $\begin{array}{l}\text { Gross Income } \\
\left(\mathrm{R} \$ \mathrm{ha}^{-1}\right)\end{array}$ & $\begin{array}{l}\text { Net Income } \\
\left(\mathrm{R} \$ \mathrm{ha}^{-1}\right)\end{array}$ & $\begin{array}{l}\text { Rate of Return } \\
\left(\mathrm{R} \$ \mathrm{R} \$^{-1}\right)\end{array}$ & $\begin{array}{l}\text { Profitability Index } \\
(\%)\end{array}$ \\
\hline Control & $8.90 \mathrm{~b}$ & $22,281.41 \mathrm{~b}$ & $10,478.48 \mathrm{~b}$ & $1.88 \mathrm{~b}$ & $46.55 \mathrm{~b}$ \\
55 & $8.72 \mathrm{~b}$ & $22,049.51 \mathrm{~b}$ & $10,316.72 \mathrm{~b}$ & $1.88 \mathrm{~b}$ & $46.42 \mathrm{~b}$ \\
70 & $9.29 \mathrm{~b}$ & $23,698.45 \mathrm{~b}$ & $11,703.53 \mathrm{~b}$ & $1.97 \mathrm{~b}$ & $49.10 \mathrm{~b}$ \\
85 & $10.49 \mathrm{~b}$ & $26,390.89 \mathrm{~b}$ & $13,814.54 \mathrm{~b}$ & $2.09 \mathrm{a}$ & $52.01 \mathrm{a}$ \\
100 & $10.28 \mathrm{~b}$ & $26,024.43 \mathrm{~b}$ & $13,551.09 \mathrm{~b}$ & $2.08 \mathrm{a}$ & $51.77 \mathrm{a}$ \\
115 & $9.80 \mathrm{~b}$ & $24,655.86 \mathrm{~b}$ & $12,413.32 \mathrm{~b}$ & $2.00 \mathrm{~b}$ & $49.96 \mathrm{~b}$ \\
130 & $9.74 \mathrm{~b}$ & $23,813.42 \mathrm{~b}$ & $11,598.79 \mathrm{~b}$ & $1.94 \mathrm{~b}$ & $48.04 \mathrm{~b}$ \\
145 & $12.43 \mathrm{a}$ & $29,812.80 \mathrm{a}$ & $16,292.08 \mathrm{a}$ & $2.20 \mathrm{a}$ & $54.58 \mathrm{a}$ \\
160 & $12.61 \mathrm{a}$ & $30,077.19 \mathrm{a}$ & $16,472.70 \mathrm{a}$ & $2.21 \mathrm{a}$ & $54.68 \mathrm{a}$ \\
190 & $11.98 \mathrm{a}$ & $30,080.43 \mathrm{a}$ & $16,778.20 \mathrm{a}$ & $2.25 \mathrm{a}$ & $55.56 \mathrm{a}$ \\
220 & $12.09 \mathrm{a}$ & $28,863.40 \mathrm{a}$ & $15,510.19 \mathrm{a}$ & $2.15 \mathrm{a}$ & $53.17 \mathrm{a}$ \\
\hline P Value & $<0.001$ & $<0.003$ & $<0.003$ & $<0.004$ & $<0.006$ \\
\hline
\end{tabular}

Note. Means within a column followed by the same letter are statistically equal to each other by the Scott-Knott test at the level of up to $5 \%$ probability.

Values corrected for inflation through the IGP-M index (FGV) in the period from October 2011 to December 2018 .

As shown in Table 4, the highest values of yield and economic indicators were observed in the intercropping treatments in which the sunn hemp was cut from 145 DAS. The amounts of fresh matter mass and nutrients incorporated into the soil may be one of the factors that provided such an outcome. Fresh matter mass values ranged from 11.06 to $42.23 \mathrm{t} \mathrm{ha}^{-1}$ for cutter treatments at 55 and $145 \mathrm{DAS}$, respectively. In relation to the amount of nutrients provided by the sunn hemp, considering the average of the cutting treatments from 55 to 130 DAS, the values in $\mathrm{kg} \mathrm{ha}^{-1}$ were: $\mathrm{N}=102.77 ; \mathrm{P}=13.73 ; \mathrm{K}=99.95 ; \mathrm{Ca}=54.77 ; \mathrm{Mg}=17.39$ and $\mathrm{S}=7.80$. On the other hand, if we consider the average of the cutting treatments from 145 to $220 \mathrm{DAS}$, the values in $\mathrm{kg} \mathrm{ha}^{-1}$ were: $\mathrm{N}=$ $140.52 ; \mathrm{P}=23.17 ; \mathrm{K}=151.42 ; \mathrm{Ca}=61.77 ; \mathrm{Mg}=28.51$ and $\mathrm{S}=11.04$.

For all the macronutrients evaluated, the values were higher in the treatments in which the cut of the sunn hemp occurred from the 145 DAS, demonstrating that it may have contributed to a higher productivity. A similar result was observed by Diniz et al. (2017) when evaluating doses of Crotalaria juncea plus $25 \mathrm{t} \mathrm{ha}^{-1}$ of organic substrate. The authors verified that the application of 6 to $9 \mathrm{t} \mathrm{ha}^{-1}$ provided higher broccoli yield when compared to the application of $3 \mathrm{tha}^{-1}$.

Another factor involved is the decomposition period of the fresh matter mass incorporated. In this sense, the synchronization between the release of nutrients and the period of greatest nutritional requirement by the broccoli plants may have been fundamental. Rodrigues et al. (2011) demonstrated that the half life $\left(\mathrm{T}_{1 / 2}\right)$ required for the decomposition of $50 \%$ of the sunn hemp dry matter mass occurred at 93 days after it was incorporated into the soil.

In the present work, in the treatments that presented higher productivity, the cut of the Crotalaria juncea occurred between 55 and 130 days after the transplanting of the broccoli. While in the treatments that presented the lowest yields, the cut occurred between 145 and 220 days, making it difficult for the broccoli to use the nutrients released by the green manure crop.

In the cultivation of maize grown in succession to broccoli and to the taro-sunn hemp intercropping, there was no significant difference between the treatments for yield values and economic indicators. The yield values of 
commercial ears ranged from 17.96 to $21.89 \mathrm{t} \mathrm{ha}^{-1}$; gross income from $\mathrm{R} \$ 11,259.06$ to $\mathrm{R} \$ 13,721.47$; net income from $\mathrm{R} \$ 4,847.77$ to $\mathrm{R} \$ 6,759.13$; rate of return from 1.75 to 1.96 and profitability ratio from 42.89 to $49.04 \%$.

For the snow pea grown in succession to green maize, broccoli and taro-sunn hemp consortium, there was no significant difference between the treatments for productivity values and economic indicators. Commercial pod yield values ranged from 5.10 to $6.89 \mathrm{t} \mathrm{ha}^{-1}$, while for economic indicators, gross income ranged from $\mathrm{R} \$ 20,089.20$ to $\mathrm{R} \$ 27,293.03$; net income from $\mathrm{R} \$ 5,088.66$ to $\mathrm{R} \$ 11,461.04$; rate of return from 1.39 to 1.76 and profitability index from $25.58 \%$ to $42.40 \%$. Table 5 shows the economic indicators values that involved the whole production process, from the implantation of the taro-sunn hemp intercropping to the snow pea harvest, the last crop grown in succession.

Table 5. Gross Income, Net Income, Rate of Return and Profitability Index of taro (Colocasia esculentum L. Schot) intercropped with sunn hemp (Crotalaria juncea), and broccoli (Brassiaca oleracea var. Itálica), green maize (Zea mays) and snow pea (Pisum sativum) grown in succession

\begin{tabular}{lllll}
\hline $\begin{array}{l}\text { Cutting regime } \\
(\mathrm{DAS})\end{array}$ & $\begin{array}{l}\text { Gross Income } \\
\left(\mathrm{R} \$ \mathrm{ha}^{-1}\right)\end{array}$ & $\begin{array}{l}\text { Net Income } \\
\left(\mathrm{R} \$ \mathrm{ha}^{-1}\right)\end{array}$ & $\begin{array}{l}\text { Rate of Return } \\
\left(\mathrm{R} \$ \mathrm{R} \$^{-1}\right)\end{array}$ & $\begin{array}{l}\text { Profitability Index } \\
(\%)\end{array}$ \\
\hline Control & $134,921.16 \mathrm{a}$ & $79,684.32 \mathrm{a}$ & $2.44 \mathrm{a}$ & $59.06 \mathrm{a}$ \\
55 & $122,707.86 \mathrm{a}$ & $68933.11 \mathrm{a}$ & $2.28 \mathrm{a}$ & $56.17 \mathrm{a}$ \\
70 & $135,429.33 \mathrm{a}$ & $79,734.30 \mathrm{a}$ & $2.43 \mathrm{a}$ & $58.87 \mathrm{a}$ \\
85 & $125,985.13 \mathrm{a}$ & $71,301.22 \mathrm{a}$ & $2.30 \mathrm{a}$ & $56.59 \mathrm{a}$ \\
100 & $126,936.18 \mathrm{a}$ & $72,092.66 \mathrm{a}$ & $2.31 \mathrm{a}$ & $56.79 \mathrm{a}$ \\
115 & $117,228.06 \mathrm{~b}$ & $63,618.06 \mathrm{~b}$ & $2.19 \mathrm{a}$ & $54.26 \mathrm{a}$ \\
130 & $121,327.52 \mathrm{~b}$ & $67,070.92 \mathrm{a}$ & $2.24 \mathrm{a}$ & $55.28 \mathrm{a}$ \\
145 & $112,116.47 \mathrm{~b}$ & $57,669.72 \mathrm{~b}$ & $2.06 \mathrm{~b}$ & $51.44 \mathrm{~b}$ \\
160 & $113,500.83 \mathrm{~b}$ & $59,899.13 \mathrm{~b}$ & $2.12 \mathrm{~b}$ & $52.77 \mathrm{~b}$ \\
190 & $106,055.30 \mathrm{~b}$ & $53,424.14 \mathrm{~b}$ & $2.01 \mathrm{~b}$ & $50.37 \mathrm{~b}$ \\
220 & $106,547.69 \mathrm{~b}$ & $53,832.81 \mathrm{~b}$ & $2.02 \mathrm{~b}$ & $50.52 \mathrm{~b}$ \\
$-\mathrm{-Valor} \mathrm{de} \mathrm{P}$ & 0.001 & $<0.001$ & $<0.001$ & $<0.001$ \\
\hline
\end{tabular}

Note. Means within a column followed by the same letter are statistically equal to each other by the Scott-Knott test at the level of up to $5 \%$ probability.

Values corrected for inflation through the IGP-M index (FGV) in the period between May/2011 (taro), October/2011 (broccoli), March/2012 (green maize) and September/2012 (snow pea) to December/2018.

The highest gross income values were obtained in the control and consortium treatment, when the sunn hemp was cut up to 100 DAS. For net income, higher values were obtained in the control and consortium treatments, with the sunn hemp cut up to 130 DAS, except for the consortium treatment in which the sunn hemp was cut at 115 DAS. On the other hand, for the rate of return and profitability index, higher values were observed in the control and consortium treatments, with the sunn hemp being cut up to 130 DAS.

Although the net income values of the control treatment did not present a significant difference in relation to some consortium treatments, being even superior to others, it is worth mentioning that in this consortium, only one crop presented commercial value, the taro. Although Crotalaria juncea has no commercial value, it provided nutrients to the crops in succession, which can be proven in the cultivation of broccoli, where the treatments that received the highest amounts of sunn hemp biomass and with a shorter period between the cutting and culture planting, presented the highest yields (Table 4). In addition, Crotalaria juncea can perform multiple functions in the soil, such as soil protection, moisture retention, temperature reduction, chemical, physical and biological conditions improvement and weed suppression (Perin et al. 2010; Guareschi et al. 2012).

In the cultivation of taro intercropped with Crotalaria juncea and the successive crops of broccoli, green maize and snow pea, with the horticultural crops being established during the most favorable climatic conditions periods, considering the economic analysis, the sunn hemp should be cut up to 130 DAS, since among other benefits, higher values of rate of return and profitability index were obtained.

The rate of return refers to the amount of resources obtained from the marketing of the products (gross income) in relation to the amount of resources spent on the implementation of crops (total operating cost). Rate of return values ranged from 2.01 to 2.44. These values were lower than those observed by Lima et al. (2014) when 
evaluating the agroeconomic viability of intercropped coriander, lettuce and arugula under different spatial arrangements. In the consortium involving the three mentioned species, the rate of return values ranged from 2.66 to 3.16. It should be noted that all crops involved have commercial value, unlike the present study in which Crotalaria juncea grown in consortium with taro is not a cash crop.

However, when the taro was cultivated as a single crop, or intercropped with Crotalaria juncea being cut until 100 DAS, disregarding the crops grown in succession, the values observed were higher than the highest value found in the consortium involving the three horticultural crops, showing a potential of financial return.

The profitability index is obtained through the relation between net income and gross income. In the present study, after harvesting the vegetables grown in succession to the consortium, the profitability index values ranged from 50.37 to $59.06 \%$. The highest profitability index values were observed for the control treatment (taro grown as a single crop) and for taro intercropped with sunn hemp, cut up to 130 DAS. When assessing the economic viability of intercropped lettuce, Indian spinach and taro in an agroecological-based farming system, Telles et al. (2018) obtained profitability index values that ranged from $-4 \%$, when planting the Indian spinach as a single crop, to $93 \%$, in the treatment in which the taro was cultivated singly. In general, the highest values were observed in the treatments in which the taro was involved, demonstrating once again, that taro is a horticultural crop that can reach high profitability indexes.

In the present work, the highest profitability index values were observed for taro cultivation, as a single crop or intercropped with Crotalaria juncea (Table 3). The values ranged from 53.55 to $71.84 \%$, being the highest those observed in the treatment of taro grown as a single crop and intercropped with Crotalaria juncea, cut up to 130 DAS.

\section{Conclusions}

When the taro is cultivated intercropped with Crotalaria juncea and in succession broccoli, green maize and snow pea are grown, higher economic yields are obtained by cutting the leguminous green manure up to 130 DAS. The use of Crotalaria juncea intercropped with taro does not affect yield or economic income when cut up to 130 DAS. The residual effect of Crotalaria juncea grown in consortium with taro increases the economic yield of broccoli when the cutting is performed from 145 DAS. There was no residual effect of Crotalaria juncea on the productivity and economic yield of green maize and snow pea grown in succession to broccoli and taro-sunn hemp intercropping.

\section{Aknowledgements}

The authors thank the Federal Institute of Espirito Santo for supporting this research.

\section{References}

ACCSEM (Associação Brasileira do Comércio de Sementes e Mudas). (2011). Dados socioeconômicos da cadeia produtiva de hortaliças no Brasil.

BCB (Banco Central do Brasil). (n.d.) Calculadora do cidadão.

Buzinaro, T. N., Barbosa, J. C., \& Nahas, E. (2009). Soil microbial activities in orchard citrus as a response to green manure cultivation. Revista Brasileira de Fruticultura, 31(2), 408-415. https://doi.org/10.1590/ S0100-29452009000200014

Cecílio Filho, A. B., Costa, C. C., Rezende, B. L. A., \& Leeuwen, R. (2008). Yield and economic feasibility of the endive and rocket intercropping, as a result of the planting time. Horticultura Brasileira, 26(3), 316-320. https://doi.org/10.1590/S0102-05362008000300005

Colombo, J. N., Puiatti, M., Filho, J. B. S., Santos, R. H. S., \& Dias, L.A.S. (2018). Intercropping of taro and sunn hemp with cutting periods during the cycle. Revista Ceres, 65(1), 35-43. https://doi.org/10.1590/ 0034-737x201865010006

Diniz, E. R., Vargas, T. O., Pereira, W. D., Santos, R. H. S., Urquiaga, S., \& Modolo, A. J. (2017). Levels of Crotalaria juncea on growth, production, recovery and efficiency of the use of $\mathrm{N}$ in broccoli. Horticultura Brasileira, 35(3), 395-401. https://doi.org/10.1590/s0102-053620170313

EMATER (Empresa de Assistência Técnica e Extensão Rural). (2012). Custo de Produção do Feijão-vagem (aspersão). Empresa de Assistência Técnica e Extensão Rural do Distrito Federal.

Guareschi, R. F., Pereira, M. G., \& Perin, A. (2012). Crop residues, light organic matter, carbon and nitrogen storage and remaining phosphorus under different management systems in the cerrado region of Goiás. Revista Brasileira de Ciencia do Solo, 36, 909-920. https://doi.org/10.1590/S0100-06832012000300021 
Helmich M., Heredia Zárate, N. A., Vieira, M. C., Faccin, F. C., Macedo, R. V., \& Maeda, A. K. M. (2010). Produção agroeconômica de três variedades de alface, cultivadas com e sem amontoa. Horticultura Brasileira, 28, S1568-S1576.

Heredia Zárate, N. A., Vieira, M. C., Sousa, T. M., \& Ramos, D. D. (2009). Yield and net income of unripe corn in function of the hilling dates. Semina: Ciencias Agrárias, 30(1), 95-100. https://doi.org/10.5433/ 1679-0359.2009v30n1p95

Lima, V. I. A., Lima, J. S. S., Neto, F. B., Santos, E. C., Rodrigues, G. S. O., \& de Paula, V. F. S. (2014). Viabilidade agroeconômica do cultivo consorciado de coentro, alface e rúcula sob diferentes arranjos espaciais. Enciclopédia Biosfera, 10(18), 3060-3069.

Melo, R. A. C. (2007). Produção e rentabilidade do brócolis de plantio direto (Dissertação de Mestrado. Faculdade de Agronomia e Medicina Veterinária, Universidade de Brasília, Brasília).

Oliveira, A. K., Lima, J. S. S., Bezerra, A. M. A., Rodrigues, G. S. O., \& Medeiros, M. L. S. (2015). Produção de rabanete sob o efeito residual da adubação verde no consórcio de beterraba e rúcula. Revista Verde de Agroecologia e Desenvolvimento Sustentável, 10(5), 98-102. https://doi.org/10.18378/rvads.v10i5.3690

Perin, A., Santos, R. H. S., Caballero, S. S. U., Guerra, J. G. M., \& Gusmão, L. A. (2010). P, K, Ca and Mg accumulation and release by sunnhemp and millet in monocrop and intercropping. Revista Ceres, 57(2), 274-281. https://doi.org/10.1590/S0034-737X2010000200020

Puiatti, M., Oliveira, N. L. C., Cecon, P. R., \& Bhering, A. S. (2015). Intercropping of taro and sunnhemp managed by cutting to the ground and pruning at canopy. Revista Ceres, 62(3), 275-283. https://doi.org/ 10.1590/0034-737X201562030007

R Core Team. (2018). R: A language and environment for statistical computing. R Foundation for Statistical Computing, Vienna, Austria.

Rezende, B. L. A., Júnior, A. P. B., Cecílio Filho, A. B., Pôrto, D. R. Q., \& Martins, M. I. E. G. (2009). Production cost and profitability of lettuce, radish, arugula and cabbage sole crop and intercropped with sweet pepper. Ciência Agrotecnologia, 33(1), 305-312.

Rodrigues L. B, Rodrigues, M. C., Araújo, J. B. S., \& Santos, R. H. S. (2011). Decomposition of Crotalaria juncea as green manure for coffee (pp. 1-4). CD-ROM of abstract of Coffee Search Symposium in Brazil. Araxá, Minas Gerais.

Telles, C. C., Junqueira, A. M. R., Fukushi, Y. K. M., Gomes, R. L., Perdomo, L. L. N., \& Koyama, A. H. (2018). Economic viability of the lettuce, bertalha and taro intercropping under agroecological crop system. Cadernos de Agroecologia, 13, 1-6.

Vargas, T. O., Diniz, E. R., Santos, R. H. S., Lima, C. T. A., Urquiaga, S., \& Cecon, P. R. (2011). Influence of the biomass of legumes on cabbage yield held in two consecutive crops. Horticultura Brasileira, 29(4), 562-568. https://doi.org/10.1590/S0102-05362011000400020

Vendruscolo, E. P., Campos, L. F. C., Arruda, E. M., \& Seleguini, A. (2017). Economic analysis of the production of crisp lettuce in successive cultivation of cover crops under no-till system. Revista Brasileira de Ciências Agrárias, 12(4), 458-463. https://doi.org/10.5039/agraria.v12i4a5478

Zanatta, J. C., Schiocchet, M. A., \& Nadal, R. (1993). Mandioca consorciada com milho, feijão e arroz de terras altas no Oeste de Santa Catarina (p. 36). Florianópolis: Empresa de Pesquisa Agropecuária e Difusão de Tecnologia de Santa Catarina.

\section{Copyrights}

Copyright for this article is retained by the author(s), with first publication rights granted to the journal.

This is an open-access article distributed under the terms and conditions of the Creative Commons Attribution license (http://creativecommons.org/licenses/by/4.0/). 